\title{
Assessing escapes from short rotation plantations of the invasive tree species Robinia pseudoacacia L. in Mediterranean ecosystems: a study in central Italy
}

\author{
Roberto Crosti ${ }^{(1-2)}$, Emiliano \\ Agrillo $^{(3)}$, Lorenzo Ciccarese ${ }^{(4)}$, \\ Riccardo Guarino ${ }^{(5)}$, Pierluigi \\ Paris $^{(6)}$, Anna Testi ${ }^{(3)}$
}

\begin{abstract}
Black locust (Robinia pseudoacacia L.) is a fast growing tree species native to temperate North America, and widely diffused and naturalized in Europe. It is one of the candidate species for establishing bioenergy plantations on marginal lands in temperate and sub-Mediterranean regions. This potential is in contrast to its well-known invasive habit, leading to a potential damage to plant biodiversity in many European countries. Advise against black locust plantation in regions where it is already invasive has been issued by several international reports, as well as the adoption of mitigation measures (e.g., "containment" buffer zones) to prevent the spread of the species into natural and semi-natural habitats. In the Mediterranean basin, however, no studies have been carried out aimed at quantifying the escape rate of black locust saplings from plantation stands and its recruitment into natural habitats, together with the effectiveness of a buffer zone in reducing the spread. In this study we investigated the spread of black locust along 35 transects surrounding three 20-year- old plantations and including three different land cover types: abandoned arable land, semi-natural woodland and a buffer zone (orchards) with a low degree of farming input. In addition, the effect of soil disturbance on seed propagation was investigated. Our results demonstrate that the density of black locust regeneration is strongly affected by the land cover, abandoned agricultural land being the most prone to black locust colonization. Contrastingly, the spread was minimal in the buffer zone and negligible in semi-natural woodland. During the investigated year, seed generative propagation was also negligible. The semi-natural woodland seems to resist well to black locust invasion, though further observations are needed to assess the consequences of stand harvesting disturbance as well, according to local standard forest management. Buffer zones seem to be very effective in controlling black locust invasion. Best management practices, with active farming inputs, are also discussed.
\end{abstract}

Keywords: False Acacia, Mediterranean Region, Risk Assessment, Containment, EU Regulation, Invasive Species services (Lavorel et al. 2011, Lafortezza et al. 2013). This is particularly true for the Quercus pubescens and Q. cerris woodlands. (Guarino et al. 2015). On the other hand, wood bioenergy is now widely recognized as a valid alternative to fossil fuels,
(1) ISPRA-IV Dipartimento, STS Palermo (Italy); (2) IUCN-CEM- Ecosystems and Invasive Species (Italy); (3) Dip. Biologia Ambientale, La Sapienza Università degli Studi di Roma (Italy); (4) ISPRA, Dipartimento Difesa della Natura; Roma (Italy); (5) Dip. STEBICEF, Università degli Studi di Palermo (Italy); (6) CNR-IBAF Porano (Italy)

@ Roberto Crosti (robertocrosti@gmail.com)

Received: Dec 11, 2014 - Accepted: Jan 28, 2016

Citation: Crosti R, Agrillo E, Ciccarese L, Guarino R, Paris P, Testi A (2016). Assessing escapes from short rotation plantations of the invasive tree species Robinia pseudoacacia $L$. in Mediterranean ecosystems: a study in central Italy. iForest 9: 822-828. - doi: 10.3832/ifor1526-009 [online 2016-05-25]

Communicated by: Andrea Cutini and its implementation in energy production systems is strongly recommended for mitigating global changes (IPCC 2014). Wood biomass for energy conversion is mostly produced by managed natural forest ecosystems, as well as by silvicultural systems specifically designed for maximizing biomass production such as short rotation forestry (SRF). However, many of the trees currently used in (or proposed for) SRF on marginal lands, such as Acacia saligna, Ailanthus altissima and Robinia pseudoacacia, are often recognized as being invasive in the Mediterranean region after weed risk assessment, due to their capacity to escape from the plantation site (Crosti et al. 2010). However, no specific study in the field has been undertaken to directly assess the escape rate of these species from tree plantations in Mediterranean Europe.

Escape from plantation sites of SRF species carrying aggressive genotypes (regardless their wild types are indigenous or not - 
Fig. 1 - Black

locust frequency distribution (in percentage, \%) in central Italy, by altitude, aspect and slope (a, b, $c$, respectively) based on more than 200 plots examined from the Georeferenced Vegetation Database of "La Sapienza" University of Rome, Italy (Agrillo et al. 2012).
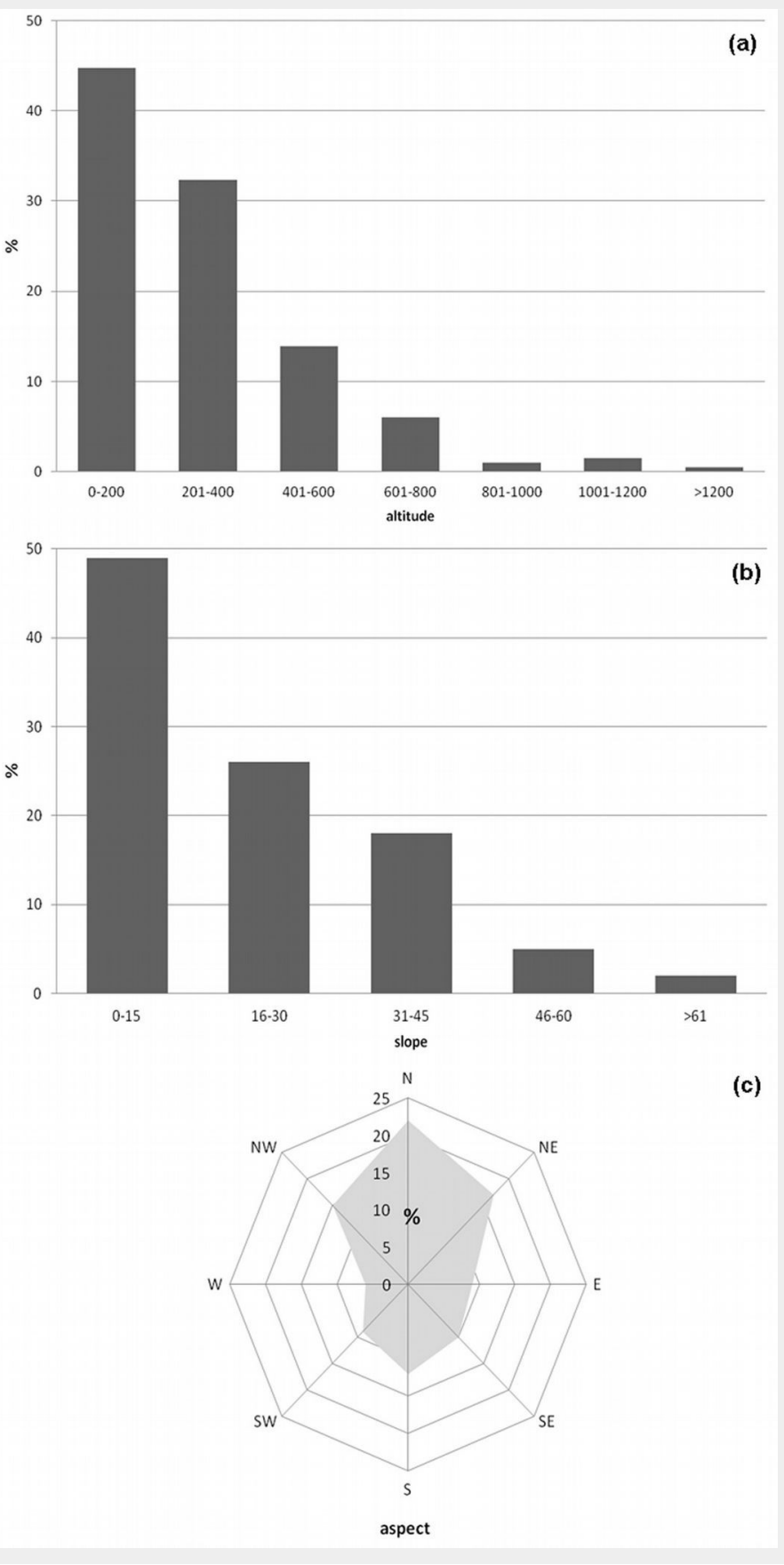

Crosti \& Leak-Garcia 2010) could harm the surrounding vegetation and the semi-natural woodlands. This includes alterations in their natural recruitment or expansion, thereby strongly affecting ecosystem services and biodiversity (Crosti \& Forconi 2007).

This research focuses on Robinia pseudoacacia (commonly named black locust, robinia or false acacia), a tree native to the north-eastern United States. It is widely planted and naturalized in many temperate areas of the world, but is also considered an invasive alien in many regions (Kleinbauer et al. 2010). In Europe, black locust is common in areas with continental subMediterranean climates with warm summers, and is still expanding and sprouting up near its plantations (Cierjacks et al. 2013) due to its strong ability to spread beyond its original place of cultivation (DAISIE 2009). At present, at least twelve varieties and several hybrids and cultivars are known (Cierjacks et al. 2013). In addition, engineering through inoculation has been undertaken to improve growth (Han et al. 1993).

Black locust was introduced in Europe in the early 1600 s and reached a wide diffusion as early as the beginning of the XIX century. In Italy, the first record in the botanical gardens of Padua dates back to 1660. Rather curiously, soon after the first European introductions, the species also reached northern Italy from France without spreading widely, so that it was reintroduced at the end of the $18^{\text {th }}$ century (Giacomini \& Fenaroli 1958). Black locust, together with Ailanthus altissima, covers an area of approximately 233.500 ha in Italy, representing $2.22 \%$ of the total forest area in Italy (Tabacchi et al. 2007). It is a nitrogen-fixing tree, and its use for bioenergy production (mainly fuelwood) is expected to increase the phytonutrient content of the soil, unlike poplar SFR plantations (Paris et al. 2015). Since the early 1990s, research programs have implanted black locust SRF plantations in Italy (mostly coppices) in order to produce biomass for industrial energy production (Gras \& Pividori 2003, Malvolti et al. 2003). Based on more than 200 plots recorded in the Georeferenced Vegetation Database of "La Sapienza" University of Rome (Agrillo et al. 2012), the most suitable site conditions for the species in central Italy are north facing and gentle slopes between 0 and $400 \mathrm{~m}$. a.s.l. (Fig. 1a, Fig. 1b, Fig. 1c). Black locust commonly occurs in stands of the thermo and meso-Mediterranean belts, together with Quercus cerris, Quercus pubescens, Carpinus betulus, Castanea sativa, Fraxinus ornus, Ostrya carpinifolia on the hills, and with Alnus glutinosa, Populus alba, Populus nigra, Quercus robur, Salix alba, Salix purpurea, Sambucus nigra along the river margins in riparian woodlands.

Black locust is an aggressive pioneer species showing several traits typical of invasive species: it can adapt to drought, easily propagates by seed and quickly resprouts from root suckers after coppicing (Lohmeyer \& Sukopp 1992). Moreover, in the Mediterranean region it has colonized a wide variety of disturbed sites, such as abandoned arable fields, dry sites, roadsides and other areas where the natural vegetation has been severely disturbed. Furthermore, black locust is regularly planted along roadsides and public open spaces. According to Boring \& Swank (1984), the abundance of black locust decreases along the natural forest succession, due to its limited competitive ability that is also supported by planting experiments (Dickmann et al. 1985).

In the introduced regions, black locust trees live longer than in the original habitat, likely due to lower herbivore pressure and fewer pathogens from the soil biota (Callaway et al. 2011). In addition, its wood is particularly resistant to insect damage (Schütt 2010, Cierjacks et al. 2013). Fruiting begins at the age of 6 years and vegetative dispersal over short distance prevails over seed dispersal. However, seeds inside the seed pod are dispersed by wind and can travel for long distances. Seeds exhibit an impermeable seed coat that allow their persistence in the seed bank; seed shedding occurs between May and September. Most of the physiological attributes of the species are undoubtedly typical of an aggressive invasive species, as described by Rédei et al. (2012). In Hungary, the species is widely used and provides significant socio-economic benefits; thus Hungary's position regarding black locust, within the framework of the recent European Union Regulation (EU) No 1143/2014 
on the "prevention and management of the introduction and spread of invasive alien species", is not to include the species in the list of invasive alien species and its management should be maintained under the scope of national legislation (EU Council 2014).

In 2009, the EU issued a Directive (2009/ $28 / E C$ ) aimed to promote the use of renewable energy, calling on member states to monitor the impact of biomass cultivation, including the displacement and introduction of invasive alien species and consequent effects on biodiversity. The Standing Committee of the Bern Convention (2009) also adopted a Recommendation (Rec. No. 141/2009) on "Potentially invasive alien plants being used as biofuel crops". According to the recommendation, contracting parties should: "avoid the use of species that are already considered invasive in the region, screen for the invasiveness of new species and genotypes, monitor the possible spread of biofuel crops into natural habitats and introduce appropriate mitigation measures to limit crop escapes". Similarly, several international organization for environment conservation (e.g., IUCN 2009) promoted guidelines to reduce the spread of biofuel species into the natural environment. Finally, according to the recent Regulation (EU) No 1143/2014, "invasive alien species of European Union concern, such as species causing significant damage in a Member State, should not be intentionally reproduced, grown or cultivated".

Although invasive, black locust has many valuable characteristics for the establishment of bioenergy plantations on marginal lands of Mediterranean countries (Paris et al. 2006, Gonzalez-Garcia et al. 2012). For example in Sicily (southern Italy) the species is largely planted under the regional reforestation scheme (La Mantia et al. 2000, RaF Sicilia 2010).

The main aim of this research is to assess black locust spread outside plantation sites by comparing its colonization of different land cover types. To this purpose, we analyzed previously established experimental plantations of black locust in an experimental area of central Italy. In addition, we investigated the effectiveness of a buffer zone (such as a tree orchard with a low degree of farming input) as a barrier against black locus spread in surrounding habitats.

\section{Materials and methods}

\section{Study area}

The research was conducted in the Biagio experimental farm managed by the Institute of Agro-environmental and Forest Biology of the National Research Council of Italy (CNR-IBAF) near the town of Orvieto (central Italy). The farm is located in the hilly area of the Monti Volsini $\left(42^{\circ} 40^{\prime} 23.61^{\prime \prime}\right.$ $\mathrm{N}, 12^{\circ} 02^{\prime} 40.12^{\prime \prime} \mathrm{E}, 550 \mathrm{~m}$ a.s.l.), approximately $50 \mathrm{~km}$ from the Tyrrhenian Sea

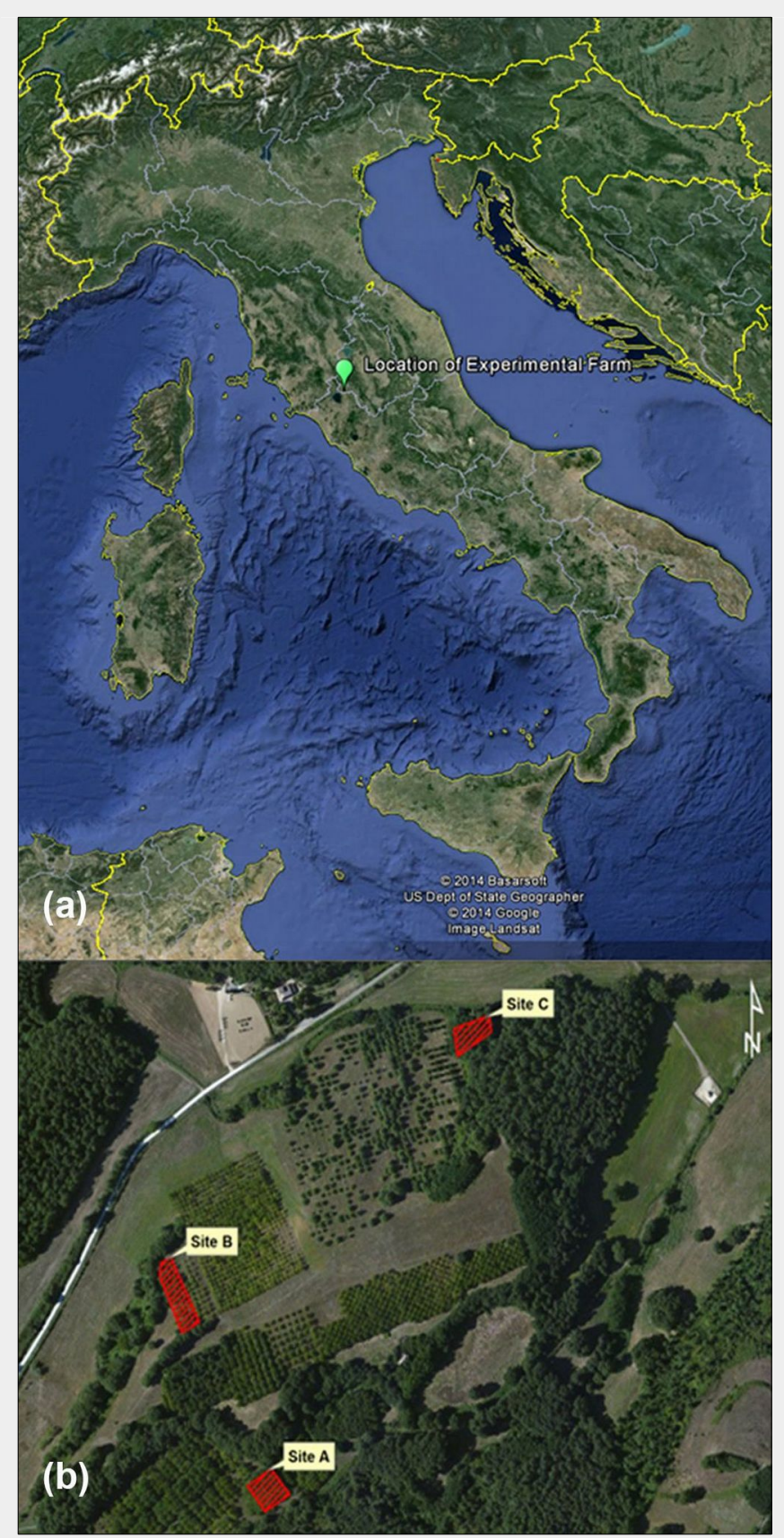

Fig. 2 - Study area (a) and black locust study plantations (b) in the CNR-IBAF Experimental Farm, municipality of Orvieto, Italy (Source: Google Earth ${ }^{\circledast}$.$$
\text { Coogle Eartho). }
$$

coast on soils of volcanic origin. The bioclimate is meso-Mediterranean (Rivas-Martínez 2007) with higher temperatures in JulyAugust and low precipitation in summer.

The farm has a total area of $22.8 \mathrm{ha}$ and is surrounded by a wire mesh fence, about 2 $\mathrm{m}$ high, which completely secludes the area from large herbivores (though the scattered presence of wild boar has been noticed). Grazing was prevented until the year before the present study, when sporadically a herd of sheep was allowed to graze inside.

\section{Black locust parental plantations}

Fig. 2 shows the location of the three black locust plantations analyzed (A, B, C) within the farm. The size of each stand is between 0.1 and 0.2 ha. The black locust trees have different genetic origins.

The area surrounding the studied planta- tions is a semi-natural warm-temperate woodland dominated by native broadleaved oaks such as Quercus pubescens and Q. cerris. In addition, there is an altered grassland vegetation growing on abandoned arable land and fruit orchard/ex situ conifers. These were the land cover types at the time of the plantations.

The main dominant native species characterizing most of the biomass cover were: (i) Quercus pubescens, Q. cerris, Crataegus monogyna, Euonymus europaeus, Acer campestre, Corylus avellana, Fraxinus ornus, Spartium junceum, and Rosa sp. pl., Rubia peregrina in the woodlands; (ii) Arisarum vulgare, Geranium rotundifolium, G. molle, Sonchus spp., Dorycnium spp., Crepis spp., Lonicera implexa, Daucus carota, Dactylis glomerata and Plantago media in the abandoned arable land. 


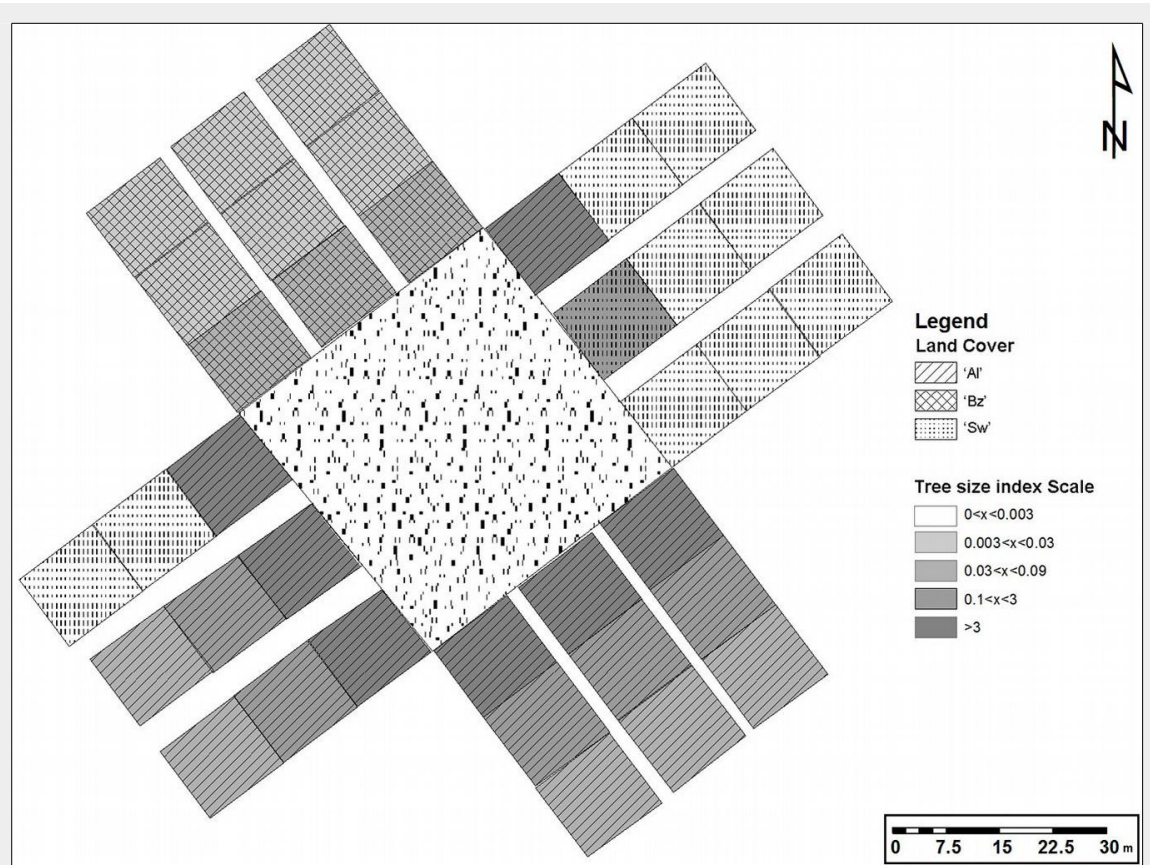

Fig. 3 - Black locust tree size for plantation $A$ in relation to land cover category and distance from the plantation edges. (Sw): Semi-natural woodland; (Al): Abandoned land; $(B z)$ : Buffer zone.

\section{Sampling}

Following Langdon et al. (2010), three perpendicular strip transects were established from the edge of each of the four sides of each plantation (Fig. 3), which totaled 35 transects (only two transects were established on the short side of stand B). Each transect was $10 \mathrm{~m}$ wide with a maximum length of $30 \mathrm{~m}$ : in some cases transects were shorter due to the presence of large roads/tracks for transit. Within each transect, starting from the edge of the black locust plantation, the presence of black locust individuals was assessed inside ninety-seven $10 \times 10-\mathrm{m}$ squared plots, which were considered as the experimental units (Fig. 3).

In each plot, the land cover type was classified in only one of the following categories: (i) semi-natural woodland ("Sw"); (ii) abandoned arable land ("Al"); (iii) tree orchard/buffer zone("Bz"). These land covers types correspond to the following $\mathrm{CO}$ RINE Land Cover classes: (i) "Sw", 3.1.1.2 Broad-leaved forest with predominance of deciduous oaks; (ii) "Al", 2.4.3.2 Agricultural areas with significant share of natural vegetation and with prevalence of grasslands; (iii) "Bz", 2.2.2.1 Orchards areas of fruit orchards and ligneous crops.

Tab. 1 - Number of plots $(10 \times 10 \mathrm{~m})$ grouped by land cover category and distance from the plantation edges.

\begin{tabular}{ccccc}
\hline $\begin{array}{c}\text { Distance } \\
(\mathbf{m})\end{array}$ & $\begin{array}{c}\text { Semi-natural } \\
\text { woodland }\end{array}$ & $\begin{array}{c}\text { Abandoned } \\
\text { land }\end{array}$ & $\begin{array}{c}\text { Buffer } \\
\text { zone }\end{array}$ & Total \\
\hline 10 & 6 & 20 & 9 & 35 \\
20 & 18 & 6 & 9 & 33 \\
30 & 14 & 6 & 9 & 29 \\
Total & 38 & 32 & 27 & 97 \\
\hline
\end{tabular}

\section{Statistical analysis}

Tree size was compared among groups (quadrates $10 \times 10 \mathrm{~m}$ grouped by land cover type, distance and site) using the General Linear Model (GLM) for unbalanced data. Tree size was considered as a function of: type of land cover, distance from the site/plantation and plantation variables. Relationships between tree size for each type of land cover and distance were also tested by calculating the Pearson's correlation coefficients. All data were checked for matching test assumptions, and no or mild violations were observed.

\section{Assessment of germination and frontal dispersal capacity}

To assess the germination capacity of black locust on disturbed soil with no vegetation, 12 germination plots of size $1 \times 1 \mathrm{~m}$ were established near the border of plantations. Germination plots were cleared and ploughed just before the natural seed shed, and the presence of emerging seedlings was recorded in the following spring.

To quantify the frontal dispersal capacity of the species, the distance of the furthest black locust from the plantation edge was recorded by lengthening the strip transects. Such measurements were taken only on one side of plantation $A$, where there is a large area of abandoned arable land and potential dispersal was more likely to occur.

To assess the reproductive capacity of the black locust individuals under investigation, an indirect test of viability ("cutting test") was applied (Rose 1915, Willian 1985, Crosti et al. 2006). Seeds from the three study plantations were collected during shedding, pooled together and then divided into four lots of 25 seeds. Each seed was opened by cutting, and seeds showing intact and healthy embryos, as well as clean and firm endosperm, were considered viable. Previous studies on black locust reported that the percentage germination of apparently viable seeds based on cutting tests was 66\% (Engstrom \& Stoekler 1941). In our study, the cutting test results revealed that most seeds $(84.3 \% \pm 12.6)$ could be considered as viable and consequently capable of germination.

\section{Results}

In the land cover category "Al" (abandoned land), black locust occurred copiously in the first $10 \mathrm{~m}$ from the plantation edge, both as saplings ( $<1 \mathrm{~m})$ and trees ( $>1$ $m$ - Tab. 2, Tab. 3), and had a high tree size value (Fig. 4). At a distance of $20 \mathrm{~m}$ from the plantation edge, tree size value decreased by approximately five times as compared with the first distance class, while the number of individuals was four times lower. At $30 \mathrm{~m}$ from the plantation tree size was about 20 times lower and the number of individuals was more than 15 times less than in the first distance class. Likewise, in the first $20 \mathrm{~m}$ from the plantation edge of the category "Bz" (buffer 
zone) both the number of saplings and tree size values were similar to the $10 \mathrm{~m}$ plots.

Contrastingly, in the land cover category "Sw" (semi-natural woodlands), very few black locust trees and saplings were found in all distance classes, and were totally absent at $30 \mathrm{~m}$ from the plantation edge (Tab. 2 - see also the tree size results from plantation A in Fig. 3). Indeed, the maximum abundance of the species in this category was in the first two-meter ecotone.

GLM analysis revealed that land cover and distance from the plantation significantly affect the black locust tree size $(\mathrm{P}<$ 0.0001 and $P<0.001$, respectively - Tab. 4$)$. On the other hand, the site/plantation showed no significant relationship with tree size ( $P=0.424$ - Tab. 4).

Pearson's correlation analysis revealed a significant negative association of tree size with "Al" ( $r=-0.73, \mathrm{df}=2, \mathrm{P}<0.001)$, and a weak negative association with "Sw" $(r=$ $-0.43, \mathrm{df}=2, \mathrm{P}<0.01)$ and "Bz" $(r=-0.51, \mathrm{df}$ $=2, \mathrm{P}<0.001$ ).

In the twelve $1 \times 1 \mathrm{~m}$ germination plots that were cleared and ploughed, only one black locust seedling was recorded during the survey, compared to five oak seedlings found in four plots.

Spontaneous frontal dispersal of black locust from plantation A was up to $44 \pm 4.6$ $\mathrm{m}$, which is equal to $2.2 \mathrm{~m}$ per year.

\section{Discussion}

In more than 20 years from the establishment of plantations, black locust had spread outside of the original stands. The colonization rate varied depending on habitat disturbance (i.e., land cover types), and was highest in the abandoned arable land area. In the semi-natural woodland, black locust occurred sporadically and does not seem to represent a threat to the natural (native) vegetation. However, these results should be regarded with caution, because since the establishment of the black locust plantations the surrounding stands (coppice-with-standards) have never been harvested, according to the local forest management records, which provide a rotation length of 30-40 years. Coppice harvesting creates large canopy gaps and determines a high disturbance of the soil. All these factors can favor the expansion of black locust, both via root suckers and seed germination, as demonstrated in coppice stands in northern Italy (Radtke et al. 2013).

Evidence of invasions by black locust in many forest types have also been reported by Maltoni et al. (2012) in areas close to our study sites. Therefore, extreme caution should be taken in establishing new black locust bioenergy plantations in the proximity of existing forests stands, because their future harvesting may create favorable conditions to black locust expansion.

It is important to consider that disturbances can also occur naturally in native vegetation, due to, e.g., wildfire, landslides,

Tab. 2 - Mean number ( \pm SE) of black locust saplings (height $<1 \mathrm{~m}$ ) in the $10 \times 10 \mathrm{~m}$ plots.

\begin{tabular}{cccc}
\hline Distance $(\mathrm{m})$ & Semi-natural woodland & Abandoned land & Buffer zone \\
\hline 10 & $0.50 \pm 0.03$ & $5.20 \pm 0.64$ & $0.80 \pm 0.07$ \\
20 & $0.05 \pm 0.003$ & $1.60 \pm 0.01$ & $0.30 \pm 0.02$ \\
30 & 0 & $0.50 \pm 0.03$ & $0.02 \pm 0.01$ \\
\hline
\end{tabular}

Tab. 3 - Mean number $( \pm \mathrm{SE})$ of black locust trees (height $>1 \mathrm{~m}$ ) in the $10 \times 10 \mathrm{~m}$ plots.

\begin{tabular}{cccc}
\hline Distance $(\mathrm{m})$ & Semi-natural woodland & Abandoned land & Buffer zone \\
\hline 10 & $0.30 \pm 0.02$ & $7.30 \pm 0.86$ & $0.20 \pm 0.014$ \\
20 & $0.01 \pm 0.001$ & $2.50 \pm 0.03$ & $0.01 \pm 0.001$ \\
30 & 0 & $0.20 \pm 0.018$ & 0 \\
\hline
\end{tabular}
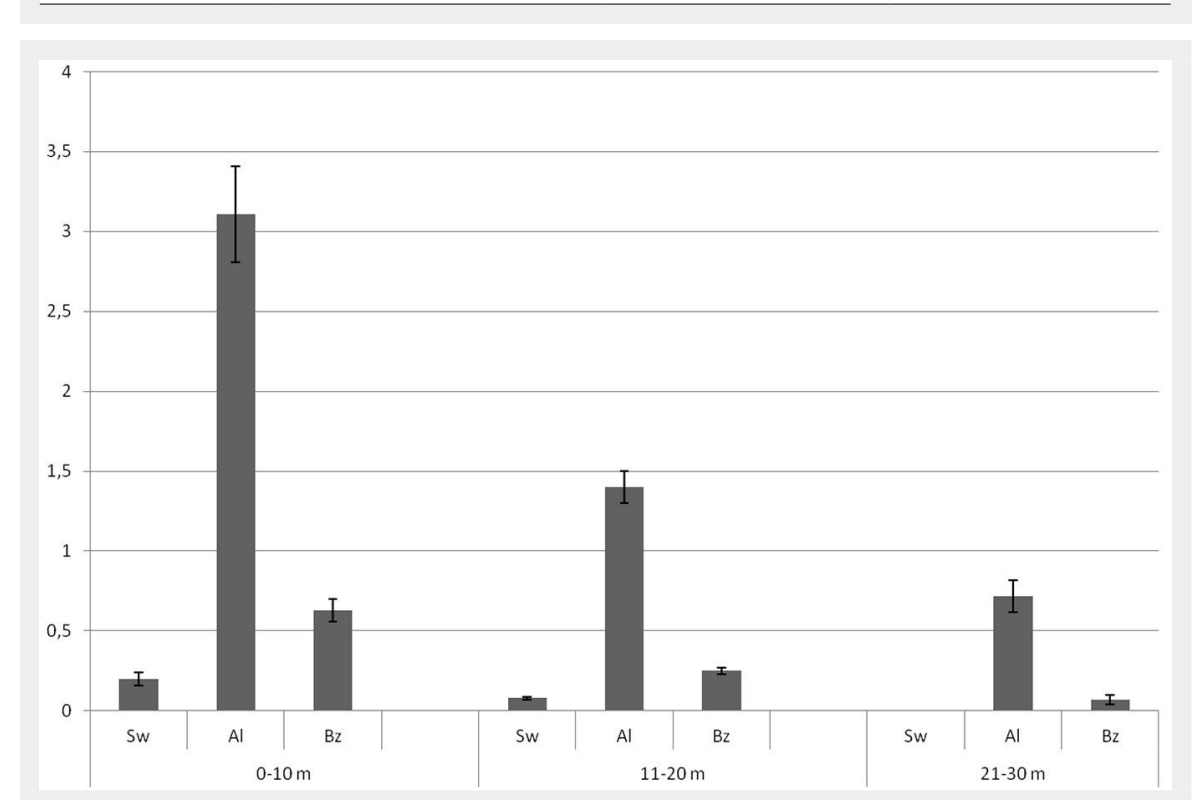

Fig. 4 - Black locust tree size values (after square root transformation) in relation to distance from the study plantation edges and land cover category. (Sw): Semi-natural woodland; (Al): abandoned land; (Bz): buffer zone.

Tab. 4 - GLM results for black locust tree size in relation to distance from the study plantation edges and micro-site land cover category.

\begin{tabular}{lccc}
\hline Source & df & F & P value \\
\hline Land cover type & 2 & 32.38 & 0.000 \\
Plantation & 2 & 0.87 & 0.424 \\
Distance & 2 & 13.17 & 0.000 \\
Error & 90 & - & - \\
\hline
\end{tabular}

severe storms, or just tree senescence. The high dispersal of invasive species (such as that originating from a black locust plantation) could hamper (or even nullify) the natural recruitment process of native species. As confirmed in our study, black locust can easily establish in the new ecotone, thus expanding the invasion front. Our study also showed that the presence of a buffer zone (in our case an orchard), with only a low degree of farming input, prevented black locust from spreading. This was likely due to the periodic cultivation practices carried out in the orchard ground floor. Indeed, farming practices are extremely efficient in suppressing both vegetative and generative reproduction of the species. This is confirmed by the fact that black locust is also an agroforestry tree species in Europe, forming tree hedgerows along field margins in agricultural landscapes, but it did not spread to nearby agro-ecosystems. This is further confirmed by recent experiences in Germany, where the impact of innovative alley cropping systems has been studied on arable lands (Medinski et al. 2015). In this agroforestry system, 10-m wide strips of trees managed as bioenergy SRF are alternated with wide alleys of arable crops and soil cultivation. Crop herbicide spraying and crop harvest are carried out in close proximity to the black locust SRF strips. However, the impact of Robinia pseudoacacia on plant biodi- 
versity (in particular on the understorey) is still under discussion. According to the literature, in the sub-Mediterranean and temperate ecosystems of central Europe, particularly in deep alluvial soils, the impact of black locust on natural vegetation seems remarkable, and in some cases it may become the dominant tree species, to the extent that a distinct phytosociological class has been recognized (Robinietea Jur ko ex Hadač \& Sofron 1980).

In Italy, the impact of black locust on the understory is still debated. Benesperi et al. (2012) found that plant communities of native tree species (Ostrya carpinifolia and Quercus cerris) are more diverse than pure black locust stands, while Sitzia et al. (2012) reported that in stands where native woody species, such as oaks and manna ash, were replaced by black locust, the latter species has only a small effect on the understory composition, as compared with secondary native stands.

By monitoring the surroundings of an 80 year old black locust plantation in Japan, Morimoto et al. (2010) found only few isolated individuals of black locust along a river up to a distance of more than $2500 \mathrm{~m}$ from the plantation. In the same study, seed traps captured seed shed approximately $70 \mathrm{~m}$ away from parent trees. Del Favero (2001) in a recent secondary woodlands including black locust trees of Colli Euganei (northern Italy) recorded a spontaneous frontal expansion in abandoned fields of approximately $2 \mathrm{~m}$ per year, which is similar to the findings of our study.

In this study, the buffer zone with active farming was very effective in blocking black locust from spreading from its plantation site. Indeed, we recorded a maximum frontal expansion of about $50 \mathrm{~m}$ after 20 years since the establishment of the plantations. However, other authors reported maximum distances of frontal expansion up to $100 \mathrm{~m}$ (Kowarik 2010, Morimoto et al. 2010). The optimal width of the buffer zone to prevent black locus escape from plantations is difficult to estimate. Nevertheless, the probability of invasive crop species to establish in a natural habitat increases with the number of propagules and their dispersal, and decreases according to the distance between the SRF and the natural habitat (Crosti 2009).

\section{Conclusions}

Several tree species proposed for bioenergy production in SRF share traits that are considered as successful in invasive species (Barney \& Ditomaso 2008). To this purpose, precautions are necessary to avoid newly-introduced species to escape from plantations, since in some cases it may take long time before their establishment in native ecosystems. Thus, species/genotypes used in SRF should be subject to preentry weed risk assessments before cultivation and to a post-entry monitoring programme.

The plot-based transect design (Langdon et al. 2010) applied in this study provided satisfactory results. The extension of similar investigation to different geographical and environmental context could improve our knowledge on the impact of blck locust on natural vegetation. Based on our results, we recommend black locust not to be planted next to sites acting as source systems, stepping stones, or ecological corridors, such as abandoned land, disturbed areas, or river banks (SRF plantations are often established close to rivers, which can act as a preferential pathway of propagule dispersal. Moreover, a managed buffer zone surrounding black locust plantations should be established to act as a biological barrier for the invasive species. Buffer zones should be planted with other (non-invasive) cultivations, although periodic ploughing or harrowing may not be sufficient to prevent resprouting of highdensity root suckers. Furthermore, the width of the buffer zone could vary depending on the dispersal distance of the invasive species. Finally, the management of woody semi-natural vegetation surrounding black locust plantations needs extreme caution in order to understand the long-term vulnerability of forest habitats to black locust invasions (Radtke et al. 2013).

\section{Acknowledgements}

This research was supported by the project PROFORBIOMED (ref. 1S-MED10009) co-financed by the European Regional Development Funds (ERDF) through the MED program. The financial and scientific assistance by Forum Plinianum (ref. 087/12/ CF-addendum Prot. 023399/2013 ISPRA) is also gratefully acknowledged. Support for the preparation of the manuscript was provided through the AGFORWARD project. We are also grateful to Dr. Carmela Cascone and Dr. Salvatore Cipollaro for their collaboration in the early stages of this project. The authors in the manuscript authorship are listed in alphabetical order, except the first author.

\section{References}

Agrillo E, Spada F, Attorre F (2012). Georeferenced vegetation database of Sapienza University of Rome. Web site. URL. [online] URL: http://www.givd.info/ID/EU-IT-011

Barney JN, Ditomaso JM (2008). Nonnative species and bioenergy: are we cultivating the next invader? BioScience 58 (1): 64-70. - doi: 10.1641/B580111

Benesperi R, Giuliani C, Zanetti S, Gennai M, Lippi MM, Guidi T, Foggi B (2012). Forest plant diversity is threatened by Robinia pseudoacacia (black locust) invasion. Biodiversity and Conservation 21 (14): 3555-3568. - doi: 10.1007/s10531012-0380-5

Boring LR, Swank WT (1984). The role of black locust (Robinia pseudoacacia) in forest succession. The Journal of Ecology 72 (3): 749-766. doi: $10.2307 / 2259529$

Callaway RM, Bedmar EJ, Reinhart KO, Silvan CG, Klironomos J (2011). Effects of soil biota from different ranges on Robinia invasion: acquiring mutualists and escaping pathogens. Ecology 92 (5): 1027-1035. - doi: 10.1890/10-0089.1 Cierjacks A, Kowarik I, Joshi J, Hempel S, Ristow M, Lippe M, Weber E (2013). Biological Flora of the British Isles: Robinia pseudoacacia. Journal of Ecology 101 (6): 1623-1640. - doi: 10.1111/13652745.12162

Crosti R, Forconi V (2007). Espansione delle colture da biomassa sul territorio italiano: incognite legate all'introduzione di specie aliene potenzialmente invasive. [Expansion of biomass crops in Italy: uncertainties associated with the introduction of potentially invasive alien species]. In: Proceedings of the Meeting "Colture a scopo energetico e ambiente. Sostenibilità, diversità e conservazione del territorio" (Forconi V, Cipollaro S, Visicchio F, Crosti R eds). APAT, Rome, Italy, pp. 49-58. [in Italian] Crosti R, Leak-Garcia JA (2010). Use of "native species" as a bioenergy crop in the Mediterranean basin. Concerns regarding invasive traits of some domesticated taxa: the case of Cardoon (Cynara cardunculus). In: Proceedings of the " 2 nd International Workshop on Invasive Plants in the Mediterranean Type Regions of the World" (Brunel S, Uludag A, FernandezGaliano Brundu G eds). Trabzon (Turkey) 2-6 Aug 2010, pp. 389-391. [online] URL: http:// archives.eppo.int/MEETINGS/2010_conferences ias trabzon/Proceedings_Trabzon_Workshop. pdf

Crosti R (2009). Invasiveness of biofuel crops and potential harm to natural habitats and native species. Report T-PVS/Inf 6, Convention on the Conservation of European Wildlife and Natural Habitats, Council of Europe, Strasbourg, France, pp. 23.

Crosti R (2011). Recruitment of Banksia spp. in an anthropogenically disturbed mediterranean climate type woodland in Western Australia. PhD thesis, Murdoch University, Perth, Western Australia, pp. 288. [online] URL: http:// researchrepository.murdoch.edu.au/10692/1/01 Front.pdf

Crosti R, Ladd PG, Dixon KW, Piotto B (2006). Post-fire germination: the effect of smoke on seeds of selected species from the central Mediterranean basin. Forest Ecology and Management 221 (1): 306-312. - doi: 10.1016/j.foreco. 2005.10.005

Crosti R, Cascone C, Cipollaro S (2010). Use of a weed risk assessment for the Mediterranean region of Central Italy to prevent loss of functionality and biodiversity in agro-ecosystems. Biological Invasions 12 (6): 1607-1616. - doi: 10.1007/s10530-009-9573-6

DAISIE (2009). Handbook of alien species in Europe. Springer, Dordrecht, Netherlands, pp. 379.

Del Favero R (2001). Progetto boschi del Parco regionale dei Colli Euganei. [Project woodlands of the regional park of the Colli Euganei]. Parco regionale dei Colli Euganei, Este, Padua, Italy, pp. 212. [in Italian]

Dickmann DI, Donald I, Steinbeck K, Skinner T (1985). Leaf area and biomass in mixed and pure plantations of sycamore and black locust in the Georgia Piedmont. Forest science 31 (2): 509-517. [online] URL: http://www.ingentacon nect.com/content/saf/fs/1985/00000031/00000 
002/art00031

Engstrom HE, Stoekler JH (1941). Nursery practice for trees and shrubs suitable for planting on the prairie-plains. Misc Pub 434, USDA Forest Service, Washington, DC, USA, pp. 159. [online] URL: http://books.google.com/books? id=L6RdAgUFaU4C

EU Council (2014). Inter Institutional File 2013/ 0307(COD)-13266/14 ADD 1. General Secretariat of the Council, Brussels, Belgium, pp. 3. [online] URL: http://register.consilium.europa.eu/doc/sr v?l=EN\&f=ST132662014ADD1

Giacomini V, Fenaroli L (1958). La flora. [Flora]. “Conosci l'Italia vol. 2". Touring Club Italiano, Milan, Italy, pp. 272. [in Italian]

Gonzalez-Garcia S, Moreira MT, Feijoo G, Murphy RJ (2012). Comparative life cycle assessment of ethanol production from fast-growing wood crops (black locust, eucalyptus and poplar). Biomass and Bioenergy 39: 378-388. - doi: 10.1016/j.biombioe.2012.01.028

Gras M, Pividori M (2003). La robinia. [The robinia]. In: “L'arboricoltura da legno: un'attività produttiva al servizio dell'ambiente” (Minotta G ed). Edizioni Avenue Media, Bologna, Italy, pp. 38-42. [in Italian]

Guarino R, Bazan G, Paura B (2015). Downy-oak woods of Italy: phytogeographical remarks on a controversial taxonomic and ecologic issue. In: "Warm-temperate deciduous forests around the Northern Hemisphere" (Box E, Fujiwara K eds). Geobotany Studies, Springer International Publishing, Switzerland, pp. 139-151. doi: 10.1007/978-3-319-01261-2_7

Hadač E, Sofron J (1980). Notes on syntaxonomy of cultural forest communities. Folia Geobotanica et Phytotaxonomica 15 (3): 245-258. - doi: 10.1007/BF02851808

Han KH, Keathley DE, Davis JM, Gordon MP (1993). Regeneration of a transgenic woody legume (Robinia pseudoacacia L., black locust) and morphological alterations induced by Agrobacterium rhizogenes-mediated transformation. Plant Science 88 (2): 149-157. - doi: 10.1016/0168-9452(93)90086-F

IPCC (2014). Climate change 2014: mitigation of climate change. Contribution of working Group III to the Fifth Assessment Report of the Intergovernmental Panel on Climate Change (Edenhofer O, Pichs-Madruga R, Sokona Y, Farahani E, Kadner S, Seyboth K, Adler A, Baum I, Brunner S, Eickemeier $P$, Krieman B, Savolainen J, Schlömer S, Stechow C, Zwickel T, Minx Ceds J eds). Cambridge University Press, Cambridge, UK and New York, NY, USA, pp. 1075.

IUCN (2009). Guidelines on biofuels and invasive species. IUCN, Gland, Switzerland, pp. 20.

Kleinbauer I, Dullinger S, Peterseil J, Essl F (2010). Climate change might drive the invasive tree Robinia pseudacacia into nature reserves and endangered habitats. Biological Conservation 143: 382-390. - doi: 10.1016/j.biocon.2009. 10.024

Kowarik I (2010). Biologische Invasionen: Neophyten und Neozoen in Mitteleuropa. [Biological invasions: new plant and animal species in Central Europe] (2 ${ }^{\text {nd }}$ edn). Ulmer, Stuttgard, Germany, pp. 492. [in German]

Kuyah S, Rosenstock TS (2015). Optimal measurement strategies for aboveground tree biomass in agricultural landscapes. Agroforestry Systems 89: 125-133. - doi: 10.1007/s10457014-9747-9

La Mantia T, Cullotta S, La Mela Veca DS (2000). Analisi degli accrescimenti di Robinia pseudoacacia L. sui Monti Peloritani (ME). [Growth analysis of Robinia pseudoacacia on the Monti Peloritani (ME, Sicily]. In: "Applicazioni e prospettive per la Ricerca Forestale Italiana" (Bucci G, Minotta G, Borghetti M eds). Ed. Avenue media, Bologna, Italy, pp. 77-79. [in Italian]

Lafortezza R, Sanesi G, Chen J (2013). Largescale effects of forest management in Mediterranean landscapes of Europe. iForest - Biogeosciences and Forestry 6 (5): 342-346. - doi: 10.3832/iforog60-006

Langdon B, Pauchard A, Aguayo M (2010). Pinus contorta invasion in the Chilean Patagonia: local patterns in a global context. Biological invasions 12 (12): 3961-3971. - doi: 10.1007/s10530010-9817-5

Lavorel S, Grigulis K, Lamarque P, Colace M, Garden D, Girel J, Pellet G, Douzet R (2011). Using plant functional traits to understand the landscape distribution of multiple ecosystem services. Journal of Ecology 99: 135-147. - doi: 10.1111/j.1365-2745.2010.01753.x

Lohmeyer W, Sukopp H (1992). Agriophyten in der vegetation Mitteleuropas. Bundesforschungsanstalt für Naturschutz und Landschaftsökologie [Naturalized species in the vegetation of Central Europe. Federal Research Centre for Nature Conservation and Landscape Ecology]. Münster-Hiltrup, Vertrieb, Landwirtschaftsverlag, Bonn-Bad Godesberg, Germany, pp. 185. [in German]

Maltoni A, Mariotti B, Tani A (2012). La gestione della robinia in Toscana [Forest management of robinia in Tuscany Region]. DEISTAF, Università di Firenze, Regione Toscana, Firenze, Italy, pp. 167. [in Italian] [online] URL: http://www. regio ne.toscana.it/-/la-gestione-della-robinia

Malvolti ME, Pollegioni $P$, Lauteri $M$, Paris $P$, Musicanti A, Pisanelli A, Mapelli S, Cannata F (2003). Robinia pseudoacacia L. Una specie da valorizzare o un'aliena da combattere? [Robinia pseudoacacia L. An alien tree species to be implemented or eradicated?] Sherwood 93: 35-44. [in Italian]

Medinski TV, Freese D, Böhm C (2015). Soil $\mathrm{CO}_{2}$ flux in an alley-cropping system composed of black locust and poplar trees, Germany. Agroforestry Systems 89: 267-277. - doi: 10.1007/s10 457-014-9764-8

Morimoto J, Ryo K, Takayoshi K (2010). Distribution and characteristics of the soil seed bank of the black locust (Robinia pseudoacacia) in a headwater basin in northern Japan. Landscape and Ecological Engineering 6 (2): 193-199. - doi: 10.1007/s11355-009-0096-1

Paris P, Sacchetti R, Scarascia Mugnozza G, Pisanelli A, Cannata F, Todaro L (2006). La robinia a turno breve vince nelle zone marginali [Robinia short rotation wins in marginal areas]. Terra e Vita 48: 79-82. [in Italian]

Paris P, Mareschi L, Sabatti M, Tosi L, ScarasciaMugnozza G (2015). Nitrogen removal and its determinants in hybrid Populus clones for bioenergy plantations after two biennial rotations in two temperate sites in northern Italy. iForest
- Biogeosciences and Forestry 8 (5): 668-676. doi: 10.3832/ifor1254-007

Radtke A, Ambraß S, Zerbe S, Tonon G, Fontana V, Ammerb C (2013). Traditional coppice forest management drives the invasion of Ailanthus altissima and Robinia pseudoacacia into deciduous forests. Forest Ecology and Management 291: 308-317. - doi: 10.1016/j.foreco.2012.11.022 RaF Sicilia (2010). Rapporto sullo stato delle foreste in SICILIA 2010 [State of forests of the Region Sicily 2010]. Coordinamento Dipartimento Regionale Comando Corpo Forestale, Regione Sicilia, Palermo, Italy, pp. 132. [in Italian]

Rivas-Martínez S (2007). Mapa de series, geoseries y geopermaseries de vegetación de España [Vegetation map of Spain: series and geopermaseries]. Itinera Geobotanica 17: 5-436. [in Spanish] [online] URL: http://air.unimi.it/ retrieve/handle/2434/232182/306485/

Rose DH (1915). A study of delayed germination in economic seeds. Botanical Gazette 59 (6): 425-444. - doi: 10.1086/331585

Rédei K, Csiha I, Keseru Z, Kamandiné Végh Á, Gyori J (2012). The silviculture of black locust (Robinia pseudoacacia L.) in Hungary: a review. SEEFOR (South-East European Forestry) 2 (2): 101-107. - doi: 10.15177/seefor.11-11

Schütt P (2010). Robinien. Bäume Nordamerikas. Von Alligator-Wacholder bis Zucker-Ahorn. Alle charakteristischen Arten im Porträt. [Robinia. Trees of North America. From Alligator Juniper (Juniperus deppeana Steud.) to Sugar Maple (Acer saccharum Marshall). A portrait of the most representative species] (Roloff $\mathrm{H}$, Weisgerber $\mathrm{H}$, Lang $\mathrm{U}$, Stimm B eds). Wiley-VCH Verlag, Weinheim, Germany, pp. 215-236. [in German]

Sitzia T, Campagnaro T, Dainese M, Cierjacks A (2012). Plant species diversity in alien black locust stands: a paired comparison with native stands across a north-Mediterranean range expansion. Forest Ecology and Management 285: 85-91. - doi: 10.1016/j.foreco.2012.08.016

Standing Committee of the Bern Convention (2009). Recommendation no. 141 of the Standing Committee of the Convention on the Conservation of European Wildlife and Natural Habitats (Bern Convention) Council of Europe, adopted on 26 November 2009, on potentially invasive alien plants being used as biofuel crops. Council of Europe, Strasbourg, France, pp. 1. [online] URL: http://wcd.coe.int/View Doc.jsp?id $=1560497 \&$ Site $=$

Tabacchi G, De Natale F, Di Cosmo L, Floris A, Gagliano C, Gasparini P, Genchi L, Scrinzi G, Tosi $V$ (2007). Le stime di superficie 2005 - Prima parte. Inventario Nazionale delle Foreste e dei Serbatoi Forestali di Carbonio [Area Estimation, 2005 - First part. National Inventory of Forests and forest Carbon pools]. MiPAAF - Corpo Forestale dello Stato - Ispettorato Generale, CRAISAFA, Trento, Italy, pp. 389. [in Italian]

Tabacchi G, Di Cosmo L, Gasparini P (2011). Aboveground tree volume and phytomass prediction equations for forest species in Italy. European Journal of Forest Research 130 (6): 911-934. - doi: 10.1007/s10342-011-0481-9

Willian RL (1985). A guide to forest seed handling with special reference to the tropics. FAO Forestry Paper, 20/2. FAO, Rome, Italy, pp. 379. 